\title{
THE CONCEPT OF "READINESS FOR PEDAGOGICAL ACTIVITY": MOTIVATIONAL READINESS, PSYCHOLOGICAL READINESS, READINESS TO INNOVATIVE ACTIVITY
}

\author{
Y.S. Seryapina, seriapinays@susu.ru \\ South Ural State University, Chelyabinsk, Russian Federation
}

\begin{abstract}
This article is a literature review that is done to compare and organize the results of the research on the concepts of "readiness" and "readiness for pedagogical activity". Readiness for pedagogical activity is an important aspect of teacher formation and self-development throughout life. The importance of the topic is justified by the fact that there is a part of academic staff that is not ready to work in new conditions due to internationalization of higher education. The processes of globalization and introduction of innovative technologies force faculty to choose between preserving traditional methods of instruction and using new innovative technologies. A survey of SUSU academic staff showed that psychological barrier and internal fear of innovation prevent them from achieving their goals and being active participants in university life. Different approaches to the notion of readiness are considered in the article, two main positions are singled out: the quality of the individual and the condition; the components of readiness are studied: motivational, psychological, cognitive and volitional. Further, the concept of "readiness for pedagogical activity", its structure and factors influencing the formation of readiness are analyzed. The article reveals the importance of the formation and development of motivational and psychological readiness for professional pedagogical activity. The changes in the motivational sphere at various stages of professionalization of an individual are considered, groups of motives for pedagogical activity are singled out.

Keywords: readiness, readiness for professional activity, innovative education, motivational readiness, psychological readiness, self-actualization.
\end{abstract}

In recent decades there has been a growing interest in higher education and we face the struggle of universities for students around the world. The number of foreign students is becoming an important factor in assessing the performance of university. Other criteria that should be mentioned are publication activity, new methods of teaching, mobility of students and faculty, etc. At the same time, academic staff is not always ready to work in new conditions, and sometimes they do not see any reason to change their teaching methods, insisting on traditional ones considering such methods to be more effective. Such attitude of faculty leads to dissatisfaction with education among students and many prefer to receive higher education abroad, believing it to be more efficient, modern and valuable.

That is why it is vital to develop psychological, professional and motivational readiness of academic staff, to improve effectiveness of teaching process and competency of faculty. As these issues are important researchers are trying to work them out and publish profound articles on these problems. As a result we can find different definitions, interpretations and scientific approaches to such concepts as "readi- ness", "readiness for professional activity", "motivational readiness", etc. So in our article we will analize the definitions given by different researchers and the ways the concepts are classified.

Let us have a look how various researchers interpret the concept of "readiness". The approaches we have studied can be divided into 2 main groups: readiness as a quality of personality (B.G. Ananyev, V.A. Kruteckiy, K.K. Platonov, R.A. Gasparyan, E.G. Kozlov, L.S. Nersesyan, A.C. Pugni, etc.), and readiness as a condition (M.I. Dyachenko, L.A. Kandybovich [4], G.N. Repetueva [22], etc.).

The authors, who hold the opinion that readiness is the quality of an individual, give the following definitions. B.G. Ananyev [1] believes that readiness is a manifestation of abilities whereas V.A. Krutetsky [11] defines it as the whole synthesis of personality qualities, as a much broader concept than just abilities. K.K. Platonov [18] distinguishes moral, psychological and professional readiness. Psychological readiness includes individual characteristics of mental processes while professional readiness is closer to the experience of the individual. L.S. Nersesyan [16], A.C. Pugni [21] determine readiness 


\section{Теория и методика профессионального образования}

through a combination of motivational, cognitive, emotional and volitional qualities of a person, a general psychophysiological state that ensures the actualization of opportunities, a route or direction for a person to perform certain actions.

L.V. Kondrashova [8] believes that readiness for activity involves the formation of such necessary relations, attitudes, characteristics and personality qualities that will give a future specialist the opportunity to fulfill his professional duties conscientiously and creatively.

A.A. Derkach [3] in his definition of readiness speaks of the holistic manifestation of all aspects of a specialist personality, highlighting cognitive, emotional and motivational components. He distinguishes the conditions for the formation of readiness for creative work:

1) independence and critical thinking;

2) active participation in solving socially important tasks;

3) development of creative abilities of an individual.

For R.D. Sanzhayeva [23] readiness is a stable characteristic of a person expressing the desire to overcome difficulties in achieving a professional goal on the basis of acquired skills and abilities. Herewith, she notes that formation of psychological readiness is closely connected with a motivational component, which is a core component because if there is no motivation and meaning then activity is impossible, even good knowledge and skills will be of no use.

M.I. Dyachenko and L.A. Kandybovich [4] take a slightly different position believing that readiness is a condition for successful performance of a professional activity. Such condition must be established and improved both by a person himself and by the state. M.I. Dyachenko and L.A. Kandybovich distinguish such components of readiness as motivational, cognitive, emotional, volitional and subdivide readiness into three groups: advance readiness (general), temporary readiness (at the moment), situational readiness (to act in this situation taking into account existing conditions).

G.N. Repetuyeva [22] suggests that readiness is a set of attitudes and connections between them, a core condition for successful performance of any activity. This fundamental condition includes knowledge, skills, attitudes, motives, ability to switch from one activity to another. In her opinion, the structure of "readiness" is represented by the following components: motivational-axiological; cognitive; activity-oriented; reflexive; informational.
It is also worth noting that according to D.N. Uznadze [27] readiness is attitude, whereas for K.M. Gurevich [5] it is proficiency, and for E.A. Klimov [7] it is connected with professional self-determination.

Having considered the above points of view of researchers, we will adhere to the position of B.G. Ananyev, V.A. Kruteckiy, K.K. Platonovand other authors who consider readiness as the quality of the individual, including the motivational, cognitive, emotional and volitional components. This position includes all the necessary components for the development of an academically mobile personality which every teacher should become, striving for high results and self-actualization.

Readiness for the professional pedagogical activity. In literature, much attention is paid to the concept of "readiness for professional pedagogical activity". Professional activity is a socially significant activity which requires special knowledge, skills, and professional qualities (E.F. Zeher [29]). "Professional readiness" is considered to be essential for effective professional activity (M.I. Dyachenko, V.S. Merlin, V.N. Myasishchev, K.K. Platonov, etc.). Professional readiness is divided into practical and theoretical. Practical readiness implies certain personal qualities, knowledge, abilities and skills that allow performing professional targets as well as functional duties. As for theoretical readiness, it includes certain knowledge about profession itself, profound professional knowledge as well as person's aptitude for the chosen profession. Talking about theoretical readiness, researchers mention ability to observe ongoing processes, analyze their progress, identify their components and establish mutual links between them, comprehend each part of any process and find the inherent patterns. To sum up theoretical readiness is closely connected with forecasting skills that include teacher's ability to foresee the result of any action before it is carried out which makes it possible to predict the development of the pedagogical process. In addition, theoretical readiness consists of planning skills which include ability to transfer goals and content of educational process into specific pedagogical tasks. This means teaching and academic staff should be able to choose necessary training tools themselves, content and the most effective methods of work from the pedagogical point of view. Practical and theoretical types of readiness are closely interrelated and include the ability to think, plan, organize, and achieve the desired objectives. 
It should be noted that some researchers consider it necessary to include a motivational aspect as an indicator of readiness (I.K. Shalaev [25]). He believes that readiness consists of both skills and abilities needed in chosen profession, and attitude towards it together with needs, desires, motives. Mindset to acquire knowledge, abilities and skills that are needed in professional activity is considered to be a core factor. Positive attitude and a certain level of development of abilities characterize professional readiness for activity.

L.A. Kondrashova [8] in her studies of readiness for pedagogical activity singles out satisfaction with the choice of pedagogical activity and the need for self-improvement as the most important indicators of readiness.

Thus, there are two key meanings of the concept of "readiness for professional activity":

a) a positive attitude, route, consent to one or another activity;

b) a condition that allow a person to perform activity effectively.

The analysis of the scientific literature on the problem of readiness for professional activity showed that there are different approaches to studying readiness for professional activity:

1) a functional approach where readiness is a special psychological state (E.P. Ilyin [6], A.S. Prangishvili [20], A.C. Pugni [21], D.N. Uznadze [27], etc.);

2) a personal approach that interprets readiness as a stable characteristic of the personality expressed in manifestation of individual qualities that contribute to the effective implementation of activities. (N.V. Kuzmina [12], A.N. Leontyev [13], V.A. Slastenin [26], etc.);

3) a personality-activity approach when readiness is viewed as a combination of personality traits and human readiness to perform necessary actions, and it is expressed in a holistic manifestation of all aspects of the personality enabling him to perform his functions effectively (M.I. Dyachenko [4], I.A. Zimnyaya [30], etc.).

Representing a personal approach to the study of readiness for professional activity M.I. Dyachenko and L.A. Kandybovich singled out the following components in its structure [4]:

- a motivational component that implies positive attitude towards activity, the need to carry out the task successfully, the desire to succeed and to show oneself in the best possible way;

- anorientational component includes knowledge and ideas about the features of professional activity, its requirements;
- anoperational component implies the possession of professional activity competences, knowledge, skills and methods;

- a strong-willed component means selfcontrol, self-mobilization;

- an evaluation component assumes assessment of its professional activity with is aimed at further improvement and self-development.

V.A. Slastenin and L.S. Podymova distinguish such components in the structure of general readiness for professional activity [26]:

- psychological readiness (focus on activity, interest and need);

- scientific and theoretical readiness (general cultural and special knowledge); skills);

- practical readiness (necessary professional

- psychophysiological readiness (person's background, professionally important personal qualities and abilities);

- physical readiness (state of health and development which is appropriate to the requirements of the profession).

We should add that V.A. Slastenin [26] links readiness with a professional focus and desire for self-actualization.

O.M. Krasnoryadtseva in her psychological research singles out such signs of readiness for professional activity [10]:

- attitude as reflection of the past experience on the current situation;

- motivational readiness to realize the meaning and value of what a peron does;

- professional-personal readiness for selfactualization through the process of personalization.

To sum up we should say there is no common point of view regarding the structural composition of readiness for professional activity that complicates the process of diagnosis.

Both external and internal factors affect the formation of readiness: makings, abilities, emotional and motivational willingness to work, the level of training, external conditions for functioning, etc.

The concept of "psychological readiness". Speaking about the willingness to work many authors highlight the psychological readiness which influences quality, stability, success of professional activity. Psychological readiness for professional activity is characterized by dynamics of changes in personal motivational sphere, professionally significant attitudes formed in a person, change in the value-semantic structure of the person's world perception [14]. 


\section{Теория и методика профессионального образования}

Some authors (L.M. Mitina [15], Y.M. Povarenkov [19], etc.) believe that psychological readiness for any professional activity is the initial component of professionalism, the premise for a successful forthcoming independent activity and the condition for the achievement of professional competences and skills.

A specialist only then becomes professionally competent when he is mobile, including academically mobile. Academic mobility is a characteristic of a person, allowing him to move for a certain period of time within his country and abroad for the purpose of training, teaching or learning, as well as the quality of the personality, closely related to the adaptation of the individual to changing social and economic conditions.

A survey among SUSU academic staff showed that $42 \%$ of those polled are psychologically unprepared for academic mobility because of fear of a new way of self-education. Psychological readiness in this case acts as a trigger mechanism of activity.

As a factor of human activity the phenomenon of psychological readiness determines much not only when a person reaches his goal but also at its beginning. Any activity begins with a person's psychological readiness to start it. There is a well-known proverb: Well begun is half done. The importance of psychological readiness to start any activity is determined primarily by difficulty of overcoming psychological barrier at the very beginning. Psychological barrier is always closely connected with doubts and hesitations associated with complexities of upcoming action. Confidence or lack of confidence is also very important at this stage.

Thus, psychological readiness provides a dynamic involvement of a person in activity as well as subsequent reliability and effectiveness of its entire strategy. It is important to note that psychological readiness is a necessary condition for effectiveness of such spheres as professional activity, person's communication and relationships with other people, person's attitude to himself, etc. [17].

Our theoretical analysis of Russian psychologists' works showed the diversity of the approaches they use when studying the psychological readiness for professional activity:

a) subject-activity: when psychological readiness is understood as the final result of training for a certain professional activity. The result includes motivational, volitional, cognitive, emotional and operational components as well as per- sonal qualities that meet the requirements of professional activity;

b) functional when readiness for activity is considered as a state of psyche which allows a specialist to achieve good results and which depends on the volume and completeness of the information received;

c) meaningful which involves the study of readiness for activity in connection with specific conditions;

d) socially-functional approach which is aimed at the study of those functions that characterize the psychological readiness in person's life;

e) structurally-psychological approach which is related to characteristic of psychological readiness elements and their interconnection;

f) genetic approach which reveals the basis of psychological readiness;

g) logico-gnoseological approach which is connected with identification of essence, content, main criteria and relationships with other indicators of psychological readiness.

Many psychologists consider the problem of psychological readiness for professional activity in accordance with the three main stages in the personality formation as a subject of professional activity [2]:

Stage 1 - education in primary and secondary school;

Stage 2 - vocational education;

Stage 3 - professional activity.

Psychological readiness for professional activity consists of the following components: motivational-axiological, personal and cognitive:

- a motivational-axiological component which consists of professionally significant motives and values that are formed on the basis of interest and positive attitude towards profession;

- a personal component which consists of professionally significant personality traits that determine professional aptitude;

- a cognitive component which consists of knowledge, skills and abilities acquired.

It is necessary to pay considerable attention not only to the content characteristics of psychological readiness for professional activity but also to such characteristics as positive attitude formation, attitude to effective professional activity, structuring and combining all psychological and psychophysiological qualities that ensure the effective professional activity performance.

Changes in the motivational sphere occur at various stages of person's professionalization [28]: 
- at the choosing a profession stage, for example, there is an interest in future profession, an understanding of profession importance and desire to join professional community;

- at the vocational training stage there is adaption to professional activity so it is possible to cool interest to a chosen profession or vice versa;

- at the mastering the profession stage there is rethinking of professional motives and goals, first satisfaction with work, desire for self-actualization;

- at the professional activity flourishing stage the motives for individual contribution to the profession and motives for professional creativity are reinforced, there is rethinking of chosen profession;

- at the professional end of a career stage there may appear motivation for self-actualization in new forms of activity, for example, in mentoring or there may be protective motivation for avoiding troubles, for example, in contrast to the professional interests of youth, regression.

In other words, at different stages of professionalization there is a different change in structure of motivation and motivational sphere, dominance of individual motivations occurs, that is, a wide variety of individual versions can be observed.

V.D. Shadrikov [24] considers the following main blocks of the functional system of activity: motives of activity; purpose of activity; program of activity; information component of the activity; making decisions; structure of professionally important qualities.

The concept of "motivational readiness". Motivational readiness of all participants of educational process to self-development, to changes in the content, methods, techniques, technologies determines meaningful and axiological levels of education. Meaningful level which characterizes internal pedagogical motivation determines its values and implies unified management, overall planning and coherence, distribution of responsibility and coordination in synergy, a common vision of the result and a choice of technologies that can help to achieve the desired result.

There are several groups of motives for pedagogical activity: motives of duty, obsession with subject, motives for communicating with students, financial motives. Motives for research and innovative work are also not homogeneous. They include motives connected with financial compensation, motives of self-affirmation among colleagues, prestige, personal success, motives of personal self-actualization, creativity, professional motives directed on increasing opportunities for students. It is important to understand what motivates a person to change and develop new qualities and skills, to search for new ways of working. The most productive way is when internal motives for self-actualization and creativity prevail over motives of avoiding failure.

Desire to work is persistent and long-lasting only with internal motives. People with internal motivation are characterized by high creativity which is accompanied by emotions of joy and satisfaction. With external motivation behavior becomes unstable so that motivation disappears with reinforcement. People with external motivation choose the simplest or standard tasks for quick remuneration, meanwhile the quality and speed of performing creative tasks are low.

It should be noted that motivated innovative behavior of a teacher is actualized only when the social professional environment allows it. Therefore, more and more often the subject of special analysis is the innovative characteristics of the environment, including the educational one. This is due to the fact that motivational readiness and, in general, innovative behavior is not formed by itself, with simple consumption of knowledge. It is important to understand that the personality changes in the process of interaction with significant individuals, a group that launches the mechanisms of personal development.

Innovative activity. Innovative activity implies faculty readiness to move away from standard methods of teaching, to make changes in the content and technology of teaching in order to increase efficiency, and thus be prepared for risks and ambiguous consequences [9].

There are different activities that innovation process of a university can be found in:

1) Development and implementation of innovative technologies in the teaching process: distance learning, electronic textbooks, wikis, weblogs, etc.;

2) Generating innovatives ideas;

3) Scientific research that can lead to "knowhow", new methods, scientific articles, etc.;

4) Special training for students and faculty in research questions;

5) Dissemination of knowledge about innovative technologies.

Innovative technologies let an academic staff guide the educational process. However, having interviewed the faculty of SUSU we came to 


\section{Теория и методика профессионального образования}

a conclusion that one forth of the staff is not ready to innovations and we can name several reasons for that:

1) Negative attitude to new tendencies: the faculty says that they do not want to change their teaching process due to the fact that new methods of teaching could be less effective;

2) Unwillingness of the staff to study, to pass exams, to change their mind, to spend time on further education;

3) Reluctance to update the process of education as it will lead to changes in the way faculty organizes lessons, implementation of some new technologies and project work that will require time to spend on preparing new tasks and plans;

4) Personal anxiety as there are teachers who are not self-assured, are afraid to express their opinion, have low self-esteem.

Thus only those teachers who are ready for self-development and further education can implement innovative technologies in their educational process. As a result they will bring up harmonious people who are ready to work and live in new environment. That will change students' attitude towards education in Russia which they suppose to be old-fashioned that make them leave the country to study abroad.

We discussed the problem of innovative education with experts in SUSU and they mentioned the following aspects of this phenomenon. First of all, they paid special attention to Information and Communication technologies that are widely used in modern system of education. Academic staff prefer to move from traditional methods of teaching to blended and distance learning when faculty starts playing the role of tutor who guides students. In such situation the role of students also changes as they themselves become responsible for their knowledge. Critical and analytical thinking, self-development and self-improvement are the main features of innovative education. Unfortunately, sometimes academic staff can have technical problems in university: not all classrooms have multimedia or interactive equipment, there are problems with internet connection, electronic textbooks should be created which also takes time, not all faculty can work with new devices easily.

Secondly, project work was mentioned as one of the most important parts of innovative education. Each department of SUSU should involve their students in project work the main idea of which is to make students solve particular problems in a creative way synthesizing knowledge from different subject areas.

Thirdly, research activity was singled out as a part of innovative education. Such activity is very important as it teaches students to decide if the problem is up-to-date, to find solutions, to choose methods for their experiment, to draw conclusions, to determine the prospects for further research. It becomes even more important if students are going to get Master's degree.

To sum up we can say that innovative activity of a university is a multidimentional activity which aims to create innovative products, technologies, services and to teach innovative methods to make faculty competitive in the worldmarket.

In conclusion, we should say that the concepts of "readiness for professional activity", "psychological readiness" and "motivational readiness" are closely interconnected, i.e. academic staff will become successful if they obtain all necessary skills and qualities that are needed in the new environment. So there are two main aims of any professional training: to develop professional skills and abilities and to create positive attitude towards the profession received. Talking about approaches to the "readiness for professional activity" we would stick to the personalactivity approach as it combines personal characteristics, psychological state and readiness itself. So faculty should be prepared to work, ready to work and have desire for self-actualization. Readiness for professional activity is closely connected with personal inclinations, abilities, emotional settings and motives, level of training, external environment, etc. Therefore effectiveness of a specialist depends both on inborn qualities and social conditions. With the proper level of faculty development of psychological and motivational readiness for professional pedagogical activity and academic mobility, he will be able to find personal fulfillment in higher education, learn how to build his own trajectory of improving skills and of personal growth, become an active participant in the system of innovative education, and expand at the international level of experience exchange.

\section{References}

1. Anan'ev B.G. Chelovek kak predmet poznaniya [Person as a Subject of Cognition]. St. Petersburg, Piter Publ., 2001. 288 p.

2. Bozhovich L.I., Fel'dshteyn D.I. Problemy formirovaniya lichnosti [Problems of Character- 
Building]. Moscow, Institut prakticheskoy psikhologii Publ., 2007. 352 p.

3. Derkach A.A. Akmeologicheskie osnovy razvitiya professionala [Acmeological Basis of Professional Development]. Moscow, Voronezh Publ., 2004. 752 p.

4. D'yachenko M.I., Kandybovich L.A. Psikhologicheskie problemy gotovnosti $k$ deyatelnosti [Psychological Problems of Readiness for Activity]. Minsk, BGU Publ., 1976. 383 p.

5. Gurevich K.M., Borisova E.M. Psikhologicheskaya diagnostika [Psychological Diagnostics]. Moscow, URAO Publ., 1997. 304 p.

6. Il'in E.P. Psikhofiziologiya sostoyaniy cheloveka [Psychophysiology of Human States]. St. Petersburg, Piter Publ., 2005. 412 p.

7. Klimov E.A. Psikhologiya professional'nogo samoopredeleniya [Psychology of Professional Self-Determination]. Moscow, Akademiya Publ., 2004. 304 p.

8. Kondrashova L.V. Vospitanie nravstvenno-psihologicheskoj gotovnosti studentov $k$ pedagogicheskoj deyatel'nosti [Education of Moral and Psychological Readiness of Students for Pedagogical Activity]. Soviet Pedagogy, 1984, no. 5, pp. 75-79. (in Russ.)

9. Kotlyarova I.O. Nepreryvnaya podgotovka studentov tekhnicheskih napravlenij $k$ innovacionnoj deyatel'nosti [Continuous Training of Technical Specialities Students for Innovation Activity]. Bulletin of South Ural State University. Ser. Education, Educational Sciences, 2012, no. 26, pp. 15-19. (in Russ.)

10. Krasnoryadtseva O.M. Chuvstvitel'nost' k problemam: ot issledovatel'skih procedur $k$ diagnostike potenciala samorealizacii lichnosti [Sensitivity to Problems: from Research Procedures to Diagnostics of Self-Actualization Potential]. Methodology and History of Psychology, 2009, vol. 4, iss. 4, pp. 73-81. (in Russ.)

11. Krutetskiy V.A. Psikhologiya [Psychology]. Moscow, Prosveshchenie Publ., 1980. 352 p.

12. Kuz'mina N.V., Rean A.A. Professionalizm pedagogicheskoy deyatel'nosti [Professionalism of Pedagogical Activity]. St. Petersburg, Rybinsk Publ., 1993. 54 p.

13. Leont'ev A.N. Deyatel'nost'. Soznaniye. Lichnost' [Activity. Consciousness. Personality]. Moscow, Smysl Publ., Akademiya Publ., 2005. $352 \mathrm{p}$.

14. Markova A.K. Psikhologiya professionalizma [Psychology of Professionalism]. Moscow, 1996, pp. 2-48. (in Russ.)

15. Mitina L.M. Psikhologiya lichnostno- professional'nogo razvitiya sub"yektov obrazovaniya [Psychology of Personal and Professional Development of Subjects of Education]. Moscow, St. Petersburg, Nestor-Istoriya Publ., 2014. $376 \mathrm{p}$.

16. Nersesyan L.S., Pushkin V.N. Psihologicheskaya struktura gotovnosti operatora $k$ ehkstremal'nym dejstviyam [Psychological Structure of the Operator's Readiness for Extreme Actions]. Question of Psychology, 1969, no. 5, pp. 24-31. (in Russ.)

17. Parygin B.D. Sotsial'naya psikhologiya [Social Psychology]. 1999. 592 p.

18. Platonov K.K. O sisteme psikhologii [About Psychology System]. Moscow, Mysl' Publ., 1972. 216 p.

19. Povarenkov Yu.P. Psikhologicheskaya kharakteristika professional'noy tolerantnosti uchitelya [Psychological Characteristics of Teacher's Professional Tolerance]. Saratov, Saratovskiy universitet Publ., 2003. 256 p.

20. Prangishvili A.S. Ustanovka $i$ deyatel'nost' [Attitude and Activity]. Question of Psychology, 1972, no. 1, pp. 3-4. (in Russ.)

21. Pugni A.Ts. Psikhologicheskaya podgotovka $k$ sorevnovaniyu $v$ sporte [Psychological Training for Competition in Sport]. Moscow, $1993.189 \mathrm{p}$.

22. Repetueva G.N. Formirovaniya gotovnosti $k$ samokontrolyu uchebno-professional'noy deyatel'nosti budushchikh pedagogov professional'nogo obucheniya $v$ protsesse izucheniya psikhologo-pedagogicheskikh distsiplin. Avtoref. kand. diss. [Formation of Readiness for SelfControl in Educational and Professional Activity of Future Vocational Training Teachers in the Process of Studying Psychological and Pedagogical Disciplines. Abstract of Cand. Diss.]. Chelyabinsk, 2009. 27 p.

23. Sanzhaeva R.D. Psihologicheskaya gotovnost' lichnosti $k$ deyatel'nosti kak metakategoriya [Psychological Readiness of a Person for Activity as a Metacategory]. Education. Personality. Society, 2012, no. 1, pp. 127-140. (in Russ.)

24. Shadrikov V.D. Vvedenie v psikhologiyu: motivatsiya povedeniya [Introduction to Psychology: Motivation Behavior]. Moscow, Logos Publ., 2003. 135 p.

25. Shalaev I.K. Motivatsionnoe programmno-tselevoe upravlenie: teoriya, tekhnologiya, praktika [Motivational Program-Target Management: Theory, Technology, Practice]. Barnaul, BGPU Publ., 2000, pp. 18-40. (in Russ.) 


\title{
Теория и методика профессионального образования
}

26. Slastenin V.A., Podymova L.S. Pedagogika: innovatsionnaya deyatel'nost' [Pedagogy: Innovation Activity]. Moscow, Magistr Publ., 1997. 224 p.

27. Uznadze D.N. Psikhologiya ustanovki [Attitude Psychology]. St. Petersburg, Piter Publ., 2001. $416 \mathrm{p}$

28. Zeer E.F., Symanyuk E.E. Krizisy professional'nogo stanovleniya lichnosti [Crises of
Professional Formation of Personality]. Psychological Journal, 2007, no. 6, pp. 64-67. (in Russ.)

29. Zeer E.F. Psikhologiya professiy [Psychology of Professions]. Moscow, Akademicheskiy Proekt Publ., Ekaterinburg, Delovaya kniga Publ., 2003. 336 p.

30. Zimnyaya I.A. Pedagogicheskaya psikhologiya [Pedagogical Psychology]. Moscow, Logos Publ., 2008. 382 p.

Received 30 September 2018

УДК 378.014.15:001.895

DOI: $10.14529 /$ ped 180410

ББК Ч 448.025

\section{ПОНЯТИЕ «ГОТОВНОСТЬ К ПЕДАГОГИЧЕСКОЙ ДЕЯТЕЛЬНОСТИ॥: МОТИВАЦИОННАЯ ГОТОВНОСТЬ, ПСИХОЛОГИЧЕСКАЯ ГОТОВНОСТЬ, ГОТОВНОСТЬ К ИННОВАЦИОННОЙ ДЕЯТЕЛЬНОСТИ}

\author{
Ю.С. Серяпина \\ Южно-Уральский государственный университет, г. Челябинск, Россия
}

\begin{abstract}
Данная статья является теоретическим обзором литературы с целью сравнения и систематизации результатов исследования понятий «готовность» и «готовность к педагогической деятельности». Готовность к педагогической деятельности является важным аспектом формирования преподавателя и его саморазвития на протяжении всей жизни. Актуальность темы готовности обосновывается тем, что большинство преподавателей университетов оказались не готовы работать в новых условиях интернационализации высшего образования. Процессы глобализации и внедрения инновационных технологий вынуждают преподавателей делать выбор между сохранением традиционных методов и технологий обучения и внедрением новых средств. Опрос преподавателей ЮУрГУ показал, что психологический барьер и внутренний страх перед инновациями мешают им достигать поставленных целей и занимать активную позицию. В статье рассмотрены различные подходы к понятию готовность, выделены 2 основные позиции: качество личности и условие, изучены компоненты готовности: мотивационный, психологический, познавательный и волевой. Далее проанализировано понятие «готовность к педагогической деятельности», его структура и факторы, влияющие на формирование готовности. В статье раскрыта важность формирования и развития мотивационной и психологической готовности к профессиональной педагогической деятельности, рассмотрены изменения в мотивационной сфере на различных стадиях профессионализации личности, выделены группы мотивов к педагогической деятельности.

Ключевые слова: готовность, готовность к профессиональной деятельности, инновационное образование, мотиваџионная готовность, психологическая готовность, самореализация.
\end{abstract}

\section{Литература}

1. Ананьев, Б.Г. Человек как предмет познания / Б.Г. Ананьев. - СПб.: Питер, 2001. - 288 с.

2. Божович, Л.И. Проблемы формирования личности / Л.И. Божович, под ред. Д.И. Фельдштейна. - М.: Ин-т практ. психологии, 2007. - 352 с. 
3. Деркач, А.А. Акмеологические основы развития профессионала / А.А. Деркач. - М.: Воронеж, 2004. - 752 c.

4. Дьяченко, М.И. Психологические проблемы готовности к деятельности / М.И. Дьяченко, Л.А. Кандьбович. - Минск: БГУ, 1976. - 383 с.

5. Психологическая диагностика / под ред. К.М. Гуревича, Е.М. Борисовой. - М.: УРАО, 1997. $304 \mathrm{c}$.

6. Ильин, Е.П. Психофизиология состояний человека / Е.П. Ильин. - СПб.: Питер, 2005. $412 \mathrm{c}$.

7. Климов, Е.А. Психология профессионального самоопределения / Е.А. Климов. - М.: Академия, 2004. - $304 \mathrm{c}$.

8. Кондрашова, Л.В. Воспитание нравственно-психологической готовности студентов к педагогической деятельности / Л.В. Кондрашова // Совет. педагогика. - 1984. - № 5. - С. 75-79.

9. Котлярова, И.О. Непрерывная подготовка студентов технических направлений к инноваичонной деятельности / И.О. Котлярова // Вестник ЮУрГУ. Серия «Образование. Педагогические науки». - 2012. - № 26. - С. 15-29.

10. Краснорядиева, О.М. Чувствительность к проблемам: от исследовательских процедур к диагностике потенциала самореализации личности / О.М. Краснорядиева // Методология и история психологии. - 2009. - T. 4. - Вып. 4. - С. 73-81.

11. Крутеикий, В.А. Психология / В.А. Крутеикий. - М.: Просвещение, 1980. - 352 c.

12. Кузьмина, Н.В. Профессионализм педагогической деятельности / Н.В. Кузьмина, А.А. Реан. - СПб.: Рыбинск, 1993. - 54 с.

13. Леонтьев, А.Н. Деятельность. Сознание. Личность / А.Н. Леонтьев. - М.: Смысл: Академия, 2005. - $352 \mathrm{c}$.

14. Маркова, А.К. Психология профессионализма / А.К. Маркова. - М., 1996. - С. 2-48.

15. Митина, Л.М. Психология личностно-профессионального развития субъектов образования / Л.М. Митина. - М.; СПб.: Нестор-История, 2014.

16. Нерсесян, Л.С. Психологическая структура готовности оператора к экстремальным действиям / Л.С. Нерсесян, В.Н. Пушкин // Вопросы психологии. - 1969. - № 5. - С. 24-31.

17. Парыгин, Б.Д. Социальная психология / Б.Д. Парыгин. - 1999. - 592 с.

18. Платонов, К.К. О системе психологии / К.К. Платонов. - М.: Мысль, 1972. - 216 с.

19. Поваренков, Ю.П. Психологическая характеристика профессиональной толерантности учителя / Ю.П. Поваренков. - Саратов: Саратов. ун-т, 2003. - 256 с.

20. Прангишвили, А.С. Установка и деятельность / А.С. Прангишвили // Вопросы психологии. 1972. - № 1. - C. 3-4.

21. Пуни, А.Ц. Психологическая подготовка к соревнованию в спорте / А.Ц. Пуни. - М., 1993. $189 \mathrm{c.}$

22. Репетуева, Г.Н. Формирования готовности к самоконтролю учебно-профессиональной деятельности будущих педагогов профессионального обучения в прочессе изучения психологопедагогических дисииплин: автореф. дис. ... канд. пед. наук / Г.Н. Репетуева. - Челябинск, 2009. $27 \mathrm{c.}$

23. Санжаева, Р.Д. Психологическая готовность личности к деятельности как метакатегория / Р.Д. Санжсаева // Образование. Личность. Общество. - 2012. - № 1. - С. 127-140.

24. Шадриков, В.Д. Введение в психологию: мотивачия поведения / В.Д. Шадриков. - М.: Ло20c, 2003. $-135 \mathrm{c}$.

25. Шалаев, И.К. Мотивационное программно-иелевое управление: теория, технология, практика / И.К. Шалаев. - Барнаул: БГПУ, 2000. - С. 18-40.

26. Сластенин, В.А. Педагогика: инновачионная деятельность / В.А. Сластенин, Л.С. Подымова. - М.: Магистр, 1997. - 224 с.

27. Узнадзе, Д.Н. Психология установки / Д.Н. Узнадзе. - СПб.: Питер, 2001. - 416 с.

28. Зеер, Э.Ф. Кризисы профессионального становления личности / Э.Ф. Зеер, Э.Э. Сыманюк // Психол. журнал. - 2007. - № 6. - С. 64-67. 
29. Зеер, Э.Ф. Психология профессий / Э.Ф. Зеер. - М.: Академ. проект; Екатеринбург: Деловая книга, 2003. - 336 с.

30. Зимняя, И.А. Педагогическая психология / И.А. Зимняя. - М.: Логос, 2008. -382 с.

Серяпина Юлия Сергеевна, аспирант кафедры безопасности жизнедеятельности, ЮжноУральский государственный университет, г. Челябинск, seriapinays@susu.ru.

Поступила в редакцию 30 сентября 2018 г.

\section{ОБРАЗЕЦ ЦИТИРОВАНИЯ}

Seryapina, Y.S. The Concept of "Readiness for Pedagogical Activity": Motivational Readiness, Psychological Readiness, Readiness to Innovative Activity / Y.S. Seryapina // Вестник ЮУрГУ. Серия «Образование. Педагогические науки». - 2018. - Т. 10, № 4. - C. 77-86. DOI: $10.14529 /$ ped 180410

\section{FOR CITATION}

Seryapina Y.S. The Concept of "Readiness for Pedagogical Activity": Motivational Readiness, Psychological Readiness, Readiness to Innovative Activity. Bulletin of the South Ural State University. Ser. Education. Educational Sciences. 2018, vol. 10, no. 4, pp. 77-86. DOI: $10.14529 /$ ped 180410 